Lenka Ptak (iD) https://orcid.org/0000-0002-9691-3298

Uniwersytet Wrocławski

lenka.ptak@uwr.edu.pl

\title{
Problematyka odmian językowych współczesnego języka czeskiego w procesie glottodydaktycznym
}

\begin{abstract}
Streszczenie
Przedmiotem rozważań w niniejszym artykule jest problematyka specyficznego rozwarstwienia współczesnego języka czeskiego, która zostanie przedstawiona w perspektywie glottodydaktycznej. Autorki skupiły się na tematyce nauczania języka czeskiego studentów bohemistyki poza granicami Republiki Czeskiej. Kwestia sytuacji językowej w Czechach stanowi duże utrudnienie zarówno dla lektorów, jak i studentów i jest przedmiotem nieustającego dyskursu metodologicznego, który wiodą czescy i zagraniczni glottodydaktycy oraz językoznawcy.
\end{abstract}

Slowa kluczowe: współczesny język czeski, glottodydaktyka, odmiany językowe, język potoczny, nieliterackie odmiany języka czeskiego

\section{Wstęp}

W procesie nauczania języka czeskiego jako obcego już od pierwszych zajęć wprowadzających napotykamy problematykę specyficznego rozwarstwienia współczesnej czeszczyzny. Kwestia ta stanowi duże utrudnienie zarówno dla lektorów, jak i studentów i jest przedmiotem nieustającego dyskursu metodologicznego, który wiodą czescy i zagraniczni glottodydaktycy oraz językoznawcy (por. Adam, 1996: 254-255). Wciąż jednak brak jest jakichkolwiek rozstrzygnięć czy wskazówek, które ułatwiłyby proces dydaktyczny.

Niniejszy artykuł poświęcony jest dwóm odmianom współczesnego języka czeskiego: odmianie oficjalnej, literackiej, realizowanej najczęściej w piśmie (,spisovná čeština”) 
oraz nieoficjalnej, potocznej, przejawiającej się przeważnie w mowie („obecná čeština”). Problematyka zostanie przedstawiona w perspektywie glottodydaktycznej, czyli podjęty zostanie aspekt specyfiki nauczania języka czeskiego przez pryzmat tychże odmian językowych, które charakteryzują się wieloma różnicami przejawiającymi się we wszystkich warstwach języka - w fonetyce, morfologii, leksyce, a nawet we frazeologii. Kwestia ta jest bardzo istotna, ponieważ owo rozwarstwienie języka czeskiego na dwie odmiany nie znajduje odzwierciedlenia w materiałach glottodydaktycznych. Podręczniki przeznaczone do nauki języka czeskiego prezentują bowiem język, którego w zasadzie nie używa się w komunikacji codziennej, a tym samym mamy w nich do czynienia z nieaktualnością rzeczową i językową tekstów. W realnej komunikacji pozycja języka literackiego jest znacznie osłabiona, jednak autorzy podręczników rzadko prezentują warstwę potoczną, a często w ogóle nie poruszają problematyki zróżnicowania języka czeskiego, co ma swoje konsekwencje w nauczaniu osób nieprzebywających na terytorium Czech i niemających codziennego kontaktu z rodzimymi użytkownikami języka. Kwestia ta nie stanowi novum, sygnalizowano ją wielokrotnie, jednak bez podania jakichkolwiek rozstrzygnięć metodologicznych. Już przed ponad dwudziestoma laty Hana Hrdličková wraz z Milanem Hrdličką w komunikacie opatrzonym symptomatycznym tytułem Spisovnost a nespisovnost ve výuce češtiny jako cizího jazyka (zob. Hrdličková, Hrdlička, 1996: 256-257) przedstawili wyniki ankiety przeprowadzonej wśród zagranicznych studentów (stypendystów i stażystów) Uniwersytetu Karola w Pradze. Wszyscy zgodnie postulowali konieczność nauczania potocznego języka czeskiego, sygnalizując ogromną rozbieżność pomiędzy językiem nauczanym w macierzystych uczelniach a językiem faktycznie używanym w codziennych sytuacjach komunikacyjnych przez rodzimych użytkowników języka. Niektórzy mówili wprost o niemożliwości prowadzenia swobodnej konwersacji, a nawet o problemach z rozumieniem języka, którego uczyli się przez kilka lat.

Zadaniem niniejszego artykułu nie jest analiza współczesnej sytuacji językowej w Czechach, jednakże uważamy, że w świetle podjętej problematyki nie można tego tematu całkowicie pominąć. Wewnętrzne zróżnicowanie czeszczyzny ma (czy raczej: powinno mieć) znaczący wpływ na nauczanie czeskiego jako języka obcego. Tymczasem do tej pory nie został określony stopień i zakres zastosowania języka nieliterackiego w procesie nauczania języka czeskiego jako obcego (w podręcznikach, programach nauczania) czy też sposób jego wdrażania. O konieczności zaznajomienia osób uczących się języka czeskiego z elementami mowy potocznej mówi się już długo, niemniej autorzy podręczników są bardzo wstrzemięźliwi w prezentacji cech tej nieoficjalnej odmiany czeszczyzny. Taka strategia jest zbieżna z założeniami bohemistów opracowujących programy kształcenia dla Czechów. Jednakże powinniśmy pamiętać, iż kształcenie językowe obcokrajowców przebiega w odmiennym kierunku - wpierw uczą się języka oficjalnego, a potem potocznego. Natomiast Czesi dopiero w szkole poznają język oficjalny, który jawi im się jako twór sztuczny i nienaturalny w codziennej komunikacji (również w przestrzeni szkolnej zob. Svobodová, 1996: 246-249), co często podkreślają w ankietach ukierunkowanych na badanie tego problemu. Jedna $\mathrm{z}$ uczennic w sondzie przeprowadzonej w połowie lat 90. XX wieku przez Radoslavę Brabcovą stwierdziła: „Ja języka oficjalnego nie używam w ogóle. Nie używam go dlatego, że od małego wszyscy mówią do mnie i w moim 
otoczeniu językiem potocznym i jestem do tego przyzwyczajona" (Brabcová, 1996: 220). Jerzy Bartmiński, określając język potoczny „pierwszym językiem” człowieka, stwierdza: „Wśród wariantów języka narodowego język potoczny, nazywany też stylem potocznym, zajmuje miejsce wyróżnione, wręcz wyjątkowe. Jest to przede wszystkim pierwszy w kolejności przyswajania wariant języka, ten, którego uczymy się w rodzinnym domu jako dzieci i który potem długo jeszcze wystarcza nam do porozumienia się w codziennych sytuacjach życiowych. Język najbardziej prosty, najbardziej konkretny, najbliższy" (Bartmiński, 1992: 38).

W związku z tym, że w glottodydaktyce cele kształcenia językowego powiązane są $\mathrm{z}$ intencjami uczących się (tzn. inne oczekiwania będą mieli studenci filologii czeskiej, inne studenci kierunków niefilologicznych uczęszczający na lektorat tegoż języka w ramach programu obranych studiów, inne uczestnicy kursu przygotowujący się do podjęcia pracy w Czechach, a jeszcze inne osoby pragnące wykorzystać ten język w celach turystycznych itp.) i ponieważ wszystkie cele ogólne, treści nauczania, zasady rozkładu materiału, metody i techniki nauczania oraz zestaw celów szczegółowych i efekty kształcenia są temu podporządkowane, uznałyśmy za istotne wskazanie grupy docelowej. W niniejszym artykule skupiłyśmy się na problematyce nauczania języka czeskiego studentów bohemistyki poza granicami Republiki Czeskiej.

\section{Odmiany języka czeskiego - „spisovná čestina” versus "obecná čestina"}

We współczesnym języku czeskim rejestrujemy kilka odmian języka. Grażyna Balowska na podstawie szczegółowych opracowań dyferencjacji języka czeskiego stworzyła model odpowiadający stratyfikacji języka polskiego ${ }^{1}$. Podział Balowskiej wygląda następująco:

- czeski język oficjalny (literacki), „,spisovná čeština”, który występuje w dwu wariantach: (a) pisany język oficjalny (literacki): ,psaná čeština”, „knižní čeština”; (b) potoczny język oficjalny (literacki): „hovorová čeština”;

- w opozycji do oficjalnej odmiany języka czeskiego stoją - z jednej strony - język czeski potoczny nieoficjalny (nieliteracki) „obecná čeština”, a z drugiej odmiany terytorialne, obejmujące interdialekty i dialekty (Balowska, 2006: 26).

Język literacki „spisovná čeština” należy do najwyższej warstwy języka narodowego, jest językiem wzorcowym, utrwalonym w gramatykach i posiada najwyższy prestiż (por. Chloupek, 1996: 33-35). Jak podkreślają definicje pojęcia spisovná čeština² (zwana dalej

1 Język polski posiada dwie odmiany: ustną (mówioną) i pisaną. Odmiana ustna występuje w dwu wariantach: oficjalnym (używanym w sformalizowanych sytuacjach publicznych i towarzyskich, np. w szkole, na egzaminie, w radiu, w urzędzie); nieoficjalnym (używanym w kontaktach codziennych, prywatnych, nieinstytucjonalnych). Wariant nieoficjalny jest określany jako język potoczny, odmiana potoczna języka ogólnego, polszczyzna potoczna lub styl potoczny (Balowska, 2006: 25). Należy też dodać, że Polacy oceniają odmianę potoczną języka zdecydowanie bardziej negatywnie (por. Habrajska, 1992: 29-31) niż Czesi, którzy uważają ten wariant językowy za neutralny i naturalny w codziennej, niewymuszonej komunikacji.

${ }^{2}$ Pojęcie spisovná čeština oznacza ,system środków językowych, które są stosowane przez użytkowników głównie w formie pisemnej oraz w oficjalnych wystąpieniach publicznych. Spisovná čeština pełni funkcję inte- 
SČ), ta literacka odmiana języka narodowego jest stosowana w oficjalnych wystąpieniach, w sferze publicznej, głównie w formie pisemnej. Podręczniki do nauki języka czeskiego jako obcego oparte są właśnie na tej odmianie. Znacznie silniejsza pozycja języka literackiego wobec nieliterackich odmian w przeszłości, widoczna zwłaszcza w obszarach, gdzie dominuje estetyczna funkcja języka, uległa stopniowej zmianie, na przykład w beletrystyce czy poezji używa się coraz częściej nieliterackich odmian języka³

Obok literackiej wersji językowej rozwija się czeszczyzna potoczna - „obecná čeština”4 (zwana dalej OČ) $)^{5}$ - która nie jest skodyfikowana i jest zależna od sytuacji i charakteru wypowiedzi nadawcy. Jest odmianą powstałą z interdialektu, który współcześnie funkcjonuje jako substandardowa odmiana mówiona. Wśród czeskich oraz zagranicznych lingwistów do chwili obecnej toczą się spory i dyskusje dotyczące klasyfikacji i dyferencjacji tejże formacji językowej (zob. Havránek, 1942; Bělič, 1958; Daneš, 1988; Čermák, 1996; Nebeská, 1996; Hronek, Sgall, 1999; Krčmová, 2000; Bermel, 2001; Čechová i in., 2003; Svobodová i in., 2011).

Wśród odmian nieliterackiej czeszczyzny OČ zajmuje specjalną pozycję. Ze wszystkich interdialektów najbardziej przenika do wypowiedzi mówionych i pisanych, silnie wpływa na świadomość językową. Coraz częściej rozpowszechniana jest w dziedzinie komunikacji publicznej i w dziennikarstwie. O silnej pozycji OČ świadczy chociażby współczesna kinematografia czeska odzwierciedlająca faktyczny, naturalny sposób komunikowania się Czechów, w której SČ występuje już tylko w formie szczątkowej bądź nie występuje wcale.

W starszych pracach językoznawczych czeszczyzna potoczna stanowi synonim (nieterminologicznego) sformułowania „lidový jazyk” (język ludowy) albo „obecný jazyk” (język potoczny), tzn. twór, który nie jest ani językiem literackim, ani też miejscowym dialektem. Określenia tego używa się do nazwania języka praktycznego, nieformalnego, a przede wszystkim mówionego, który jest środkiem komunikacji werbalnej. W takim rozumieniu obecnie mówimy o odmianie językowej nazywanej „,běžně mluvený jazyk” albo „běžná mluva” (język mówiony, język używany na co dzień), w której stosowane są środki językowe w większości mieszane, niepodporządkowane regułom poprawnościowym języka (zob. Karlík, Nekula, Pleskalová, 2002).

\footnotetext{
gracyjną i jest reprezentatywna dla narodu. Jest skodyfikowana w gramatykach, słownikach, zasadach pisowni i wymowy. Nie jest jednorodna, posiada wiele warstw stylowych, funkcjonalnych i regionalnych" (Karlík, Nekula, Pleskalová, 2002: 90-91). Słownik języka czeskiego Slovnik spisovné češtiny definiuje pojęcie spisovný następująco: używany w literaturze, w prasie, w miejscach publicznych oraz w komunikacji urzędowej, np. spisovný jazyk; spisovná čeština (język); spisovný tvar (forma), výraz (wyrażenie, zwrot); spisovná výslovnost (wymowa) (Slovník spisovné češtiny: 405).

3 Tendencje do stosowania w literaturze pięknej elementów OČ nasiliły się po roku 1989 - stanowiły wówczas m.in. zewnętrzny wyraz potrzeby zamanifestowania przez twórców swobody w wymiarze intelektualnym, obyczajowym i politycznym (zob. Mielczarek, 2014).

${ }^{4} \mathrm{~W}$ polskiej literaturze przedmiotu powszechnie stosuje się termin czeski obecná čeština (zob. Szczepańska, 2003; Balowska, 2006; Mielczarek, 2014).

5 W naszym artykule posługujemy się skrótem OČ, ogólnie przyjętym w pracach czeskich i polskich lingwistów i literaturoznawców (zob. Szczepańska, 2003; Kotková, 2009; Mrázková, 2013; Hrdlička, 2014; Boccou Kestř́nková, 2017). Analogicznie skrót SČ - „spisovná čeština”.
} 
Współcześnie „obecná čeština” klasyfikowana jest jako język komunikacji prywatnej i półpublicznej, regionalnie i społecznie mało naznaczony, który z pozycji jednej z niestandardowych form języka czeskiego awansował do jego substandardu. Nowa modyfikacja OČ zajmuje w komunikacji pozycję wcześniej zarezerwowaną wyłącznie dla języka literackiego. W odróżnieniu na przykład od mówionych odmian polszczyzny używana jest w wypowiedziach mówionych spoza sfery prywatnej, a co istotne, jest częstym środkiem porozumiewania się także wśród wykształconych warstw społeczeństwa, bowiem jej nacechowanie pod względem społecznym jest osłabione (zob. Karlík, Nekula, Pleskalová, 2002; Mielczarek, 2014).

Odmiana potoczna czeszczyzny różni się znacząco od oficjalnego języka czeskiego nie tylko pod względem leksykalnym i syntaktycznym (podobne różnice występują również w innych językach), ale także pod względem fonetycznym i morfologicznym. Do najbardziej charakterystycznych cech OČ należą:

- dyftongizacja ý/í > ej, np. w miejsce mlýn, být, prý, malý dům, ten samý występuje mlejn, bejt, prej, malej diom, ten samej;

- zamiana é > ý/í, np. mlíko, malý město, lítat, je to teplí zamiast mléko, malé město, létat, je to teplé;

- wstawienie protetycznego $v$ - przed nagłosowym o-, np. vokno, von, vodmítnout, vomdlit;

- skracanie długiej samogłoski w ostatniej sylabie, np. domu, dávam, myslim, nevim, prosim, ř́kam zamiast domů, dávám, myslím, nevím, prosím, říkám;

- ujednolicenie końcówek narzędnika liczby mnogiej we wszystkich rodzajach, stosowanie końcówki -ma, np. w miejsce (s) těmi dobrými lidmi, cizími ženami, třemi malými městami występuje (s) těma dobrejma lidma, cizejma ženama, třema malejma městama;

- jedna końcówka dla wszystkich rodzajów w mianowniku liczby mnogiej przymiotników, np. hezký hoši, hezký ženy, pěkný kot’ata zamiast hezcí hoši, hezké ženy, pěkná kot'ata;

- pominięcie końcowego - $l \mathrm{w}$ formie imiesłowu czasu przeszłego dla rodzaju męskiego, np. (on) ved, řek, pomoh zamiast (on) vedl, řekl, pomohl;

- pomijanie czasownika posiłkowego být $\mathrm{w}$ formie czasu przeszłego, np. já to věděl, my to nevěděli, já byl, my mysleli, já přijel zamiast já jsem to věděl, my jsme to nevěděli, já jsem byl, my jsme mysleli, já jsem prijiel.

Zjawisko występowania dwóch kodów w obrębie jednego języka nazywane jest dyglosją. Zgodnie z klasyczną definicją Charlesa Fergusona dyglosja oznacza współistnienie dwóch odmian tego samego języka pełniących różne funkcje komunikacyjne. Podczas gdy pierwsza, tzw. wysoka, jest ustandaryzowana i nabywana jest wyłącznie na drodze formalnej edukacji, i jest używana w kontekstach formalnych, odmiana druga, tzw. niska, jest przyswajana spontanicznie jako pierwszy język i jest używana w zwykłej komunikacji codziennej i we wszystkich kontekstach nieformalnych (zob. Ferguson, 1959). Sytuacja języka czeskiego nie jest jednak typowo dyglosyjna, ponieważ nie chodzi tu o przełączanie kodów, ale raczej o ich wymieszanie (zob. Krčmová, 2000; Bermel, 2001). 
Nie ma wątpliwości, że stosowanie OČ w przekazie publicznym oraz w mediach, które są przecież dla obcokrajowców uczących się czeskiego i przebywających poza granicami Czech najczęstszym kontaktem z językiem, ma wpływ także na naukę języka. W związku z tym powstaje pytanie, czy i kiedy wprowadzić w procesie nauczania języka czeskiego dla obcokrajowców nieliterackie odmiany języka.

\section{2. „Obecná čeština” w procesie nauczania języka czeskiego jako języka obcego}

W nauczaniu języka czeskiego jako obcego regularnie zmagamy się z problemem włączenia OČ do procesu nauczania. Z występowaniem dwóch wariantów językowych (,spisovná čeština” i „obecná čeština”) w nauczaniu czeskiego jako języka obcego związane są następujące problemy:

1. Czy włączyć OČ do procesu nauczania?

2. Jeżeli tak, to kiedy rozpocząć wdrażanie OČ?

3. W jakim stopniu/zakresie i w jaki sposób wprowadzić OČ?

4. W jaki sposób zapewnić, by umiejętności nabyte w zakresie jednej odmiany zostały zachowane także przy nauczaniu drugiej odmiany?

Lektorzy języka czeskiego borykają się od wielu lat z tym samym problemem - czy język powszechnie używany w mowie należy włączać do procesu dydaktycznego, czy nie. A jeśli tak, to kiedy rozpocząć jego wdrażanie, w jakim stopniu i w jaki sposób. Biorąc pod uwagę, że interesującą nas grupą docelową są osoby uczące się języka czeskiego poza granicami Czech, wychodzimy z założenia, że osoby te w pierwszej kolejności poznają język literacki, a z odmianą potoczną muszą się w jakiś sposób zapoznać. Cudzoziemiec uczący się języka czeskiego bywa w większości uczestnikiem komunikacji ustnej, dlatego też kwestia potocznej odmiany języka czeskiego jest w jego edukacji tak ważna. Dialogi prezentowane w niektórych materiałach dydaktycznych odpowiadają bardziej normom pisemnym niż standardom języka mówionego i mogą wydawać się nieodpowiednie i sztuczne. Autorzy podręczników tworzą dialogi, których nie ma w języku mówionym i które bywają w dużym stopniu nienaturalne, w wyniku czego powstaje swoisty rodzaj konwersacji literackiej.

Podejście komunikacyjne, którego nadrzędnym celem jest osiągnięcie przez osobę uczącą się umiejętności efektywnego porozumiewania się w danej sytuacji (Komorowska, 2001: 27), nie tylko zmieniło w glottodydaktyce metodologię, ale wpłynęło też na treści nauczania, które zaczęły w coraz większej mierze uwzględniać język mówiony, czyli tym samym język potoczny (w kontekście języka polskiego jako obcego poruszyła tę kwestię Tambor, 2010: 312-314). Pociągnęło to za sobą również przesunięcie nacisku z kompetencji stricte lingwistycznych na rzecz kompetencji socjolingwistycznych i pragmatycznych (zob. Janowska, 2011: 28-29). W tym momencie pojawia się dla lektorów zagranicznych problem, z którym muszą poradzić sobie sami. Nie mają wsparcia w podręcznikach, ponieważ materiały dydaktyczne do nauczania języka czeskiego jako obcego nie są dostosowane do wprowadzenia do procesu dydaktycznego potocznego języka czeskiego. 
Lektorzy mają co prawda do dyspozycji autentyczne teksty (np. z Czeskiego Korpusu Narodowego - Pražský mluvený korpus), nagrania, teksty piosenek, teksty z filmów ${ }^{6}$, jednakże wprowadzenie OČ do procesu nauczania wymaga wówczas od nauczyciela dużo pedagogicznych umiejętności i ogromnego wkładu pracy własnej.

Większość materiałów dydaktycznych języka czeskiego dla obcokrajowców prezentuje jedynie oficjalną wersję języka. Autorzy podręczników do nauki czeskiego nie zawsze podkreślają różnice między oficjalną SČ a potoczną OČ. To, że podręczniki bazują głównie na zasobach językowych literackiego języka czeskiego, uważamy za pożądane. Zgadzamy się z poglądem czeskiej badaczki Marii Boccou Kestřánkovej, że SČ dla obcokrajowca uczącego się języka czeskiego jest punktem odniesienia, a używając formy literackiej, może porozumieć się w każdym zakątku Czech i do tego nie jest wymagana znajomość innych wariantów czeskiego języka narodowego (Boccou Kestránková, 2016: 76). Z drugiej zaś strony w podręcznikach czy w samym procesie nauczania potrzebne są dialogi typowe dla wypowiedzi powstającej w sytuacji nieformalnej, w codziennych kontaktach życiowych. Jak już wspomniano, w komunikacji codziennej, ale także w literaturze, filmach i mediach regularnie spotykamy się z mieszaniem środków językowych reprezentatywnych dla każdej z odmian. Jak wskazuje Lída Holá, zarówno literacka SČ, jak i potoczna OČ są poprawnymi i usankcjonowanymi wariantami języka, z których każdy jest odpowiedni do użycia w innej przestrzeni, w innej sytuacji i innym sformułowaniu wypowiedzi. Ta przesłanka jest bardzo ważna, jednakże wcale nie oczywista. W tym kontekście nie należy apriorycznie postrzegać mieszania kodów jako czegoś z gruntu złego, ale raczej opierać się na stwierdzeniu, że takie mieszanie kodów jest charakterystyczne dla obecnej sytuacji językowej (Holá, 2008).

Jeżeli przyjrzymy się bliżej podręcznikom takim jak Čeština pro život 1 (Nekovářová, 2008) oraz Čeština pro život 2 (Nekovářová, 2012), przeznaczonym dla osób znajdujących się odpowiednio na poziomie B1 oraz B2, zauważymy, że publikacja została oparta prawie wyłącznie na czeskim języku oficjalnym SČ - język potoczny objawia się sporadycznie. Podręcznik ten opatrzony został podtytułem 15 moderních konverzačních témat (15 współczesnych tematów konwersacyjnych), w którym zawarty został jasny przekaz, iż jest on przeznaczony do wzbogacenia umiejętności prowadzenia rozmowy na bieżące tematy, a więc powinien zawierać potoczny język czeski. Pomimo zasygnalizowanego w tytule komunikacyjnego nachylenia podręcznika brak w nim jakichkolwiek odniesień do problematyki stratyfikacji współczesnego języka czeskiego, a słownictwo z warstwy potocznej pojawia się w nim sporadycznie.

W oparciu o naszą wiedzę i doświadczenie uważamy, że uczący się języka czeskiego są w stanie opanować wybrane elementy OČ (i odróżniać je od SČ), jeżeli zostaną dotrzymane pewne zasady. Już od samego początku nauczania języka czeskiego należy zapoznawać studentów z problematyką dyferencjacji języka czeskiego, trzeba przestrzegać

${ }^{6}$ Lektorzy mogą wykorzystać różnego rodzaju samodzielnie przygotowane ćwiczenia, takie jak uzupełnianie luk w tekście; ćwiczenia, w których wyrazy z odmiany oficjalnej SČ zamieniane są na potoczną OČ i odwrotnie; ćwiczenia, w których należy przyporządkować wyrazy do definicji; zaznaczanie elementów OČ w tekstach (zob. przykłady ćwiczeń Čeština pro středně a více pokročilé - Bischofová, 2011: 242-245; Česky krok za krokem 2 Holá, Bořilová, 2009). 
zasad regulujących wybór pomiędzy środkami obydwu odmian w zależności od funkcji komunikacyjnej oraz kontekstu społecznego. Jest to możliwe nawet we wczesnych etapach nauki, jednak należy sygnalizować funkcjonalność stylową tekstów, przede wszystkim w tworzeniu dialogów przedstawiających typowe sytuacje komunikacyjne, które zazwyczaj dominują na niższych poziomach edukacji, czerpiąc z zasobów językowych (głównie leksykalnych i syntaktycznych) charakterystycznych dla języka mówionego (por. Holá, 2008). Już od samego początku nauki otwiera się dla lektorów możliwość wyboru w dialogach formy bliższej komunikacji mówionej na przykład spośród zwrotów (já) děkuju/ děkuji/dik/diky albo form czasownikowych (já) studuju/studuji, (oni) pracujou/pracuji oraz (já) můžu/mohu. Student opanowuje takie zwroty czy formy czasownikowe, posługując się prostymi dialogami, wielokrotnie nie znając innych paradygmatów. Nauczyciel w takich momentach ma okazję zwrócić uwagę na fakt, iż (já) děkuju/studuju/můžu czy (oni) pracujou są formami podstawowymi używanymi w codziennej komunikacji, natomiast (já) děkuji/studuji/mohu oraz (oni) pracuji to formy używane głównie w formalnej komunikacji pisemnej lub w formalnej komunikacji ustnej.

Jak słusznie zauważa Milan Hrdlička, OČ powinna być prezentowana osobno od języka literackiego i w sposób kompleksowy, czyli w pełnym opisie - należy przedstawić wszystkie płaszczyzny tej odmiany językowej, a nie tylko stronę gramatyczną. Zgadzamy się z autorem, że różnice między standardem a substandardem powinny być podkreślane konsekwentnie. Autor przeprowadził analizę podręczników do nauki czeskiego jako obcego pod względem prezentacji gramatyki, a w monografii Gramatika a výuka češtiny jako cizího jazyka. K prezentaci gramatiky českého jazyka v učebnicích češtiny pro cizince poruszył zagadnienie sposobu przedstawienia stratyfikacji języka czeskiego. Na podstawie przeprowadzonej analizy stwierdził, że nie ma obecnie wystarczających informacji na temat stratyfikacji języka czeskiego narodowego w podręcznikach do języka czeskiego dla obcokrajowców, a oprócz tego pojawia się w nich cały szereg niedociągnięć. Często mieszane są gramatyczne i leksykalne zasoby obu wariantów (oficjalnego i potocznego), brakuje precyzji w stosowaniu wyrażeń i zwrotów (mieszanie fraz książkowych i neutralnych z potocznymi itp.). Taka sytuacja jest według Hrdlički niepożądana, ponieważ bardzo komplikuje - jeśli nie uniemożliwia - osiągnięcie odpowiednich umiejętności językowych i komunikacyjnych w języku czeskim przez obcokrajowców uczących się tego języka (Hrdlička, 2009: 128).

Lektorzy języka czeskiego powinni pamiętać, że należy przestrzegać różnic pomiędzy pisaną i mówioną odmianą komunikacji, a do procesu nauczania wdrażać takie teksty i ćwiczenia, które są charakterystyczne dla danej sytuacji komunikacyjnej. Dobrym przykładem wykorzystania OČ w komunikacji mówionej jest podręcznik Česky krok za krokem 2, w którym w tekstach do słuchania przeważają rozmowy z elementami OČ. Są to przede wszystkim dialogi nieformalne zwłaszcza między kolegami, jak na przykład w dialogu w lekcji 9 (CD 1/49):

Páni, mě bolí záda! Já už nevim, co s tim mám dělat.

A proč nejdeš na masáž? To by ti třeba pomohlo.

Ty znáš nějakýho dobrýho maséra?

No, u nás na sídlišti je jeden moc šikovnej. Byl jsem tam minulej tejden, strašnĕ mě

bolely záda z volejbalu. Moc mi pomoh. Musíš si k němu taky zajít. 
A musim se k němu objednat?

Musišs, má pořád plno. Dám ti telefonní čislo. ${ }^{7}$

Autorki podręcznika Česky krok za krokem 2 poświęcają dużo uwagi OČ, wyraźnie podkreślając różnice między oficjalną SČ a potoczną OČ. Elementy OČ pojawiają się w każdej lekcji.

Ciekawe rozwiązania (choć ukazane tylko sygnalnie, w kilku miejscach) przynosi też podręcznik pt. New Czech step by step, w którym tematyka dialogów oraz sytuacja komunikacyjna odzwierciedlana jest także w obranej odmianie językowej. Formalne dialogi, na przykład osób niebędących na ty, pisane są w SČ, natomiast luźna rozmowa młodych osób, które spotkały się przypadkowo na ulicy, prowadzona jest w OČ (Holá, 2006: 61).

Jeżeli chodzi o nauczanie wymowy, należy ją oprzeć na fundamentach języka literackiego. W komunikacji mówionej Czesi skracają długie samogłoski. Dotyczy to przede wszystkim samogłosek í oraz ú. Skracana jest często długa samogłoska w ostatniej sylabie, np. domu, dávam, myslim, nevim, prosim, ř́kam zamiast domů, dávám, myslím, nevím, prosím, ríkám. W przypadku dwóch identycznie brzmiących wyrazów w języku czeskim iloczas jest cechą istotną, ponieważ może różnicować znaczenie, np. czasownik dal 'dał'- przysłówek dál 'dalej', rzeczownik dráha 'droga, tor' - przymiotnik drahá 'droga, drogocenna', czasownik pierwszej osoby liczby pojedynczej myji 'myję'- czasownik trzeciej osoby liczby mnogiej myji 'myją', rzeczownik mysli 'myśli' - czasownik myslí '(on) myśli', rzeczownik spála 'szkarlatyna' - czasownik spala 'spała', rzeczownik žíla 'żyła' - czasownik žila 'żyła'. Jak widzimy, długość samogłoski albo, odwrotnie, brak długości może mieć decydujący wpływ na znaczenie wyrazów.

Zdena Palková zwraca uwagę, że w nauczaniu mowy dobrą podstawę stanowi standard odmiany literackiej, ponieważ ma stabilne wzorce słuchowe głosek, jego zastosowanie stylowe jest jednoznaczne - a rodzimy odbiorca właśnie takiego standardu od obcokrajowca oczekuje. Jednakże podczas rozwijania zdolności percepcyjnych należy czerpać nie tylko z SČ, ale także z zasobów OČ. W nauczaniu każdego języka obcego, w tym czeskiego, ważne jest, aby rozwijać percepcyjne składniki języka (słuchanie), które są ściśle powiązane ze wzbogacaniem umiejętności w zakresie słownictwa i gramatyki (Palková, 1985: 97-105).

\section{Podsumowanie i wnioski}

Jak pokazano, w dydaktyce języka czeskiego jako obcego wewnętrzne zróżnicowanie języka narodowego w sposób znaczący komplikuje cele dydaktyczne i sam proces nauczania. Kwestia sytuacji językowej w Czechach i status OČ w ramach czeskiego języka narodowego $\mathrm{w}$ dużym stopniu odzwierciedla się $\mathrm{w}$ danej problematyce. $\mathrm{W}$ procesie dydaktycznym należy uwzględniać aspekt komunikacyjny i jego ważkość dla osób uczących się języka czeskiego

7 Elementy OČ oraz słownictwo typowe dla potocznej odmiany języka czeskiego zostały przez nas wyróżnione pogrubioną czcionką. Nagranie jest dostępne również na http://www.czechstepbystep.cz/studenti/nahravky_ckzk2.

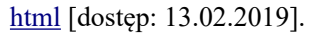


i zapewniać jego aplikację w odpowiedni sposób. Za Antonim Furdalem należy przypomnieć, że: „Podstawowym typem języka jest język potoczny. Określany tym mianem język używany jest przez społeczeństwo dla celów przede wszystkim komunikatywnych, choć nie wyłączając emocjonalnych i poznawczych, bez których żaden język istnieć nie może” (Furdal, 1977: 151).

Przyglądając się materiałom dydaktycznym języka czeskiego przeznaczonym dla obcokrajowców, można stwierdzić, że nie zawierają (z wyjątkiem kilku nielicznych) języka potocznego OČ, co uważamy za niezadowalające. Autorzy podręczników do języka czeskiego raczej unikają włączania OČ do materiału dydaktycznego, przez co dialogi stają się nienaturalne. Język stosowany w podręcznikach zdecydowanie różni się od obecnej językowej sytuacji w Czechach. A przecież, parafrazując konstatację Danuty Buttler z połowy lat 80. XX wieku, do przeszłości należy już ten okres rozwoju dydaktyki języków obcych, kiedy to uwaga wykładowcy koncentrowała się niemal wyłącznie na wdrożeniu uczniom znajomości kategorii gramatycznych, co powodowało, iż z tak przyswajanego języka student nie miał ,żadnego życiowego pożytku, nie mógł się nim posługiwać w kontaktach z rdzennymi użytkownikami danego języka, nie wywołując ich rozbawienia sztuczną, nieświadomie archaizowaną formą wypowiedzi” (Buttler, 1980: 154).

Już od samego początku nauczania języka czeskiego należy przestrzegać zasad regulujących wybór pomiędzy środkami obydwu odmian w zależności od funkcji komunikacyjnej oraz rzeczywistości pozajęzykowej, czyli kontekstu społecznego. Najbardziej odpowiednim sposobem wprowadzenia OČ do podręczników wydaje się poświęcenie przynajmniej jednej kompletnej lekcji OČ oraz stosowanie różnych uwag, odsyłaczy na łamach całego podręcznika. Pozwoliłoby to na systematyczne i konsekwentne wprowadzanie elementów OČ do nauki języka czeskiego już w najwcześniejszych poziomach nauki, a jednocześnie nie prowadziłoby do mieszania odmian w późniejszych etapach kształcenia. Różnice pomiędzy odmianą oficjalną i nieoficjalną języka czeskiego powinny być wskazywane także w podręcznikach dla osób zaawansowanych językowo. Dotyczy to zwłaszcza pracy z leksyką, którą należy wprowadzać zawsze w powiązaniu z daną sytuacją komunikacyjną, podkreślając różnice w komunikacji oficjalnej i nieoficjalnej. Zmiana ukierunkowania nauczania na podejście komunikacyjne powinna zaowocować także nowymi pod względem metodycznym podręcznikami. Prezentacja OČ powinna być w nich kompleksowa, skupiona na płaszczyźnie zarówno morfologicznej, jak i leksykalnej, a także fonetycznej czy stylistycznej w ten sposób, by osoby uczące się mogły posługiwać się formami językowymi charakterystycznymi dla oficjalnej SČ i nieoficjalnej OČ odpowiednio do danej sytuacji.

\section{Bibliografia}

Adam H. (1996), Problematika spisovnosti a nespisovnosti z hlediska češtiny jako cizího jazyka, [w:] R. Šrámek (red.), Spisovnost a nespisovnost dnes, Brno.

Adamovičová A., Pešička J. (2006), Běžně mluvenýjazyk ve výuce češtiny pro cizince, „Sborník Asociace učitelů češtiny jako cizího jazyka", 2005-2006.

Balowska G. (2006), Problematyka czeszczyzny potocznej nieliterackiej (tzw. obecná čeština) na łamach czasopisma „Naše reč” w latach dziewięćdziesiatych, „Bohemistyka”, nr 16. 
Bartmiński J. (1992), Styl potoczny, [w:] J. Anusiewicz, F. Nieckula (red.), Język a kultura, t. 5: Potoczność w języku i w kulturze, Wrocław.

Bělič J. (1958), Vznik hovorové češtiny a její poměr k češtině spisovné, [w:] Československé prednášky pro 4. mezinárodní sjezd slavistů v Moskvě, Praha.

Bermel N. (2001), Střídaní kódů či míšení jazykových prostředků? K popisu dialogu v české beletrii, „Naše řeč”, LXXXIV.

Bischofová J. i in. (2011), Čeština pro středně a více pokročilé, Praha.

Boccou Kestráńnková M. (2017), Postavení obecné češtiny ve výuce češtiny pro cizince, „Studie z aplikované lingvistiky", 2.

Brabcová R. (1996), Škola a spisovná čeština, [w:] R. Šrámek (red.), Spisovnost a nespisovnost dnes, Brno.

Buttler D. (1980), Dobór wyrazów do słownika - minimum języka polskiego, [w:] J. Lewandowski (red.), Metodyka nauczania języka polskiego jako obcego, Warszawa.

Čechová M., Chloupek J., Krčmová M., Minářová E. (2003), Současná česká stylistika, Praha. Čermák F. (1996), Obecná a spisovná čeština: Poměr, funkce a metodologie, [w:] R. Šrámek (red.), Spisovnost a nespisovnost dnes, Brno.

Chloupek J. (1996), Spisovná čeština jako formální varieta národního jazyka, [w:] R. Šrámek (red.), Spisovnost a nespisovnost dnes, Brno.

Čmejrková S. (2006), Spisovnost a nespisovnost, „Sborník Asociace učitelů češtiny jako cizího jazyka", 2005-2006.

Cvrček V. i in. (2010), Mluvnice současné češtiny, Praha.

Daneš F. (1988), Pojem „,spisovného jazyka” v dnešních společenských podmínkách, [w:] Dynamika současné češtiny z hlediska lingvistické teorie a společenské praxe, Praha.

Ferguson Ch. (1959), Diglossia, „Word”, 15.

Furdal A. (1977), Językoznawstwo otwarte, Opole.

Habrajska G. (1992), Potoczność w rozumieniu potocznym, [w:] J. Anusiewicz, F. Nieckula (red.), Język a kultura, t. 5: Potoczność w języku i w kulturze, Wrocław.

Havránek B. (1942), K funkčnímu rozvrstvení spisovného jazyka, „Časopis pro Moderní Filologii”, XXVIII.

Holá L. (2006), New Czech step by step, Praha.

Holá L. (2008), Spisovná vs. obecná čeština ve výuce češtiny jako cizího jazyka, [w:] E. Hájková, K. Šebesta (red.), Didaktické studie IV, Čština jako druhý jazyk, Praha, http://www. czechstepbystep.cz/clanky/spisovna_sv obecna.html [dostęp: 13.02.2019].

Holá L., Bořilová P. (2009), Česky krok za krokem 2, Praha.

Hrdlička M. (2002), Cizí jazyk čeština, Praha.

Hrdlička M. (2009), Gramatika a výuka češtiny jako cizího jazyka: k prezentaci gramatiky českého jazyka v učebnicích češtiny pro cizince, Praha.

Hrdličková H., Hrdlička M. (1996), Spisovnost a nespisovnost ve výuce češtiny jako cizího jazyka, [w:] R. Šrámek (red.), Spisovnost a nespisovnost dnes, Brno. 
Hronek J., Sgall P. (1999), Sbližování spisovné a obecné češtiny, „Naše řeč”, LXXXII.

Janowska I. (2011), Podejście zadaniowe do nauczania i uczenia się języków obcych. Na przykładzie języka polskiego jako obcego, Kraków.

Karlík P., Nekula M., Pleskalová J. (2002), Encyklopedický slovník češtiny, Praha.

Komorowska H. (2002), Metodyka nauczania języków obcych, Warszawa.

Kotková R. (2009), Nespisovné útvary ve vyučování češtiny, „Usta ad Albim”, IX, nr 1.

Krčmová M. (2000), Termín obecná čeština a různost jeho chápání, [w:] Z. Hladká, P. Karlík (red.), Čě́tina - univerzália a specifika 2, Brno.

Mielczarek J. (2014), Stratyfikacja odmian języka czeskiego a ksztaltowanie się wartości estetycznych wspótczesnej czeskiej prozy (zarys ujęcia teoretycznego), [w:] W. Pskit (red.), Semantyczne i pragmatyczne aspekty komunikacji. Od deminutywów do gestów, Łódź.

Mrázková K. (2013), Obecná čeština v SSJČ a v lingvistické bohemistice obecně, „Jazykovědné Aktuality", L, nr 3 i 4.

Nebeská I. (1996), Jazyk, norma, spisovnost, Praha.

Nekovářová A. (2006), Čeština pro život 1, Praha.

Nekovářová A. (2012), Čeština pro život 2, Praha.

Palková Z. (1985), Fonetická problematika při výuce češtiny jako ciziho jazyka, [w:] Čeština jako cizí jazyk, Sborník FF UK, Praha.

Slovnik spisovné češtiny pro školu a veřejnost (2005), J. Filipec, F. Daneš, J. Machač, V. Mejstř́k (red.), Praha.

Svobodová J. (1996), Mluvená „spisovnost” ve škole, [w:] R. Šrámek (red.), Spisovnost a nespisovnost dnes, Brno.

Svobodová J. i in. (2011), Fenomén spisovnosti v současné české jazykové situaci, Ostrava.

Szczepańska E. (2003), Obecná čeština w literaturze czeskiej, „Bohemistyka”, 4.

Tambor J. (2010), Granice potoczności w nauczaniu języka polskiego jako obcego. Przemiany leksykalne, fonetyczne, fleksyjne i słowotwórcze we współczesnej polszczyźnie, [w:] R. Nycz, W. Miodunka, T. Kunz (red.), Polonistyka bez granic, t. 2: Glottodydaktyka polonistyczna.

\section{Abstract \\ On the language varieties of the contemporary Czech language in the glottodidactic process}

This paper presents some difficulties with the teaching issue of the varieties of the contemporary Czech language in teaching process. The paper is focused on the competition between standard and non-standard varieties of Czech language when teaching Czech as a foreign language. It concerns especially the situation of the Czech colloquial language so called "obecná čeština", sometimes considered as a specific case of language diglossia. One of the main aims is to discuss the appropriateness of using a colloquial language when teaching Czech as a foreign language, so when a student of Czech language, learning only standard language, meets with nonstandard Czech, it would not lead to a complete misunderstanding.

Keywords: colloquial language, Czech language, glottodidactics, non-standard language, the variety of the language 